\title{
Michat Borwicz in Kraków from 1911 to 1939. INTRODUCTION TO THE ISSUE ${ }^{1}$
}

\author{
Stefan Gąsiorowski \\ https://orcid.org/0000-0002-5984-5337 \\ (Jagiellonian University, Krakow) \\ e-mail: st.gasiorowski@uj.edu.pl
}

Keywords: Michał Borwicz, Maksymilian Boruchowicz, Kraków, literature, Jagiellonian University, Nazism, novel

\begin{abstract}
This article discusses the early life of Maksymilian Boruchowicz (1911-1987), a Jewish writer, publicist, and literary critic known in interwar Kraków, who changed his name to Michał Borwicz after the Second World War. Biographical information on his life before the outbreak of the war focuses mainly on his studies of Polish language and literature at the Jagiellonian University, where he was actively involved in student literary and cultural circles, as well as political journalism. During his studies and immediately thereafter, Borwicz published prolifically in various magazines and literary journals, and before the war published the novel Miłość $i$ rasa (Love and Race), which was received positively by literary critics.
\end{abstract}

\section{Introduction}

Dr. Michał Borwicz (1911-1987), scholar, critic, publicist, poet, and emigrant, is not well-known among literary and other historians, in particular those specializing in the Second World War. Despite the many significant events of his life (including the following during the war: escaping from captivity, working in the underground, averting death by hanging and escaping from an extermination camp in Lviv, working for the Central Jewish Historical Commission, and carrying out scientific work in exile in the USA and France), as well as his literary and social activity, and despite the many preserved source documents thereon, albeit dispersed and in different languages, there is no personal biography on him to date.

A year after Michał Borwicz's death, in the third volume of the annual Polin, a brief biographical article was published by Rafael Felix Scharf, one of the founders of the Institute for Polish-Jewish Studies in Oxford and Polin itself. ${ }^{2}$ Like Scharf, Borwicz was from Kraków and spent nearly half his life in the city. It may therefore be worth

1 This article was written based on a paper presented at "New Perspectives in Jewish Historiography," an academic conference held in Kraków on 2 March 2017 celebrating the publication of the 29th volume of Polin. Studies in Polish Jewry.

${ }^{2}$ Scharf 1988: 458-462. 
mentioning some little-known facts about him from his time there (which was no less interesting or creative than his times in Lviv, the USA, or Paris) from source materials of the National Archives in Kraków, the Jagiellonian University Archives, and the Polish Library in Paris. I will also attempt to verify some of his biographical data, which is sometimes presented incorrectly in small or occasional publications.

\section{Childhood and secondary school}

Michał Borwicz was born Maksymilian Boruchowicz in Kraków (not in Tarnów as some sources claim ${ }^{3}$ ) on 11 October 1911 into the Jewish family of Adolf Abraham and Anna née Rosenwald, which was most likely assimilated. ${ }^{4}$ His father was a small-time merchant who lost his job before WWII, and his mother most likely abandoned him when he was in secondary school. His education began in primary school. As Rafael Scharf recalled years later, Boruchowicz was expelled from several secondary schools due to his lively temperament. He ended up at the Professor Stanisław Jaworski Junior High School for Boys in Kraków, where he studied the humanities. ${ }^{5}$ In addition to Polish language and history, he took classes in religion, Latin, German, mathematics, physics, and introductory philosophy. He was exempt from physical education (for unknown reasons), which at the time was referred to as "physical exercise." It is also worth mentioning that for one year he was a classmate of Józef Cyrankiewicz (1911-1989), a prime minister of the Polish People's Republic (PRL).

He passed his final high school exam on 2 June 1930. It consisted of written exams in Polish (for which he received a mark of "very good"), German ("good"), history ("very good"), and mathematics ("good"), and oral exams in Polish ("very good") and mathematics ("good"). The questions from both oral exams have been preserved. During the Polish oral examination, he was asked to discuss two topics: 1) Jan Kasprowicz (1860-1926; poet and representative of Young Poland) and Dies irae (a hymn written by the poet; Latin for "Day of Anger"), the progression of his thought, and the nature of the hymn and similar works. 2) The significance of Kasprowicz's work for Polish literature. The task for the mathematics section concerned logarithms (the inverse operation of exponentiation). ${ }^{6}$

\section{University studies}

That same year, Maksymilian Boruchowicz began studying Polish language and literature at the Department of Philosophy of the Jagiellonian University (album No. 4782). He studied over a period of seven years, due to breaks between his second and third years and his fourth and fifth years. Why he took the first break is unknown (possibly

${ }^{3}$ Quercioli Mincer 2014:187.

${ }^{4}$ Gawron 2014: 123.

5 Scharf 1988: 458.

${ }^{6}$ Final high school examination report. No. 5. June 1930. National Archives in Kraków, ref. GMJ 24, sheet 245, 249v; GMJ 84, sheets 17-17v. 
for military training; despite being exempt from physical education in high school, he was a "category $\mathrm{A}^{\text {" }}$ ). For the second break, he received permission from the dean of the Jagiellonian University Department of Philosophy, Professor Tadeusz Lehr-Spławiński, most likely in connection with his father's loss of employment. ${ }^{8}$

During his university studies, Boruchowicz lived with his father, first at 22 Pawia Street, and from 1936 at 3 Przemyska Street, in the Jewish Academic House. In 1937, his father moved to Lagiewniki, at the time a village south of Kraków. After his father lost his job, Boruchowicz made a living tutoring, most likely Polish. However, this job was just a stopgap measure, and did not earn him a sufficient income. He therefore attempted to pay his tuition fees in two or three installments (successfully) and even defer payment. $^{9}$

What probably intrigued Boruchowicz the most at that time was attending lectures by the greatest celebrities of the university, including linguists Zenon Klemensiewicz (1891-1969) and the aforementioned Tadeusz Lehr-Spławiński (1891-1965), linguist and Slavist Kazimierz Nitsch (1874-1958), literary historians Ignacy Chrzanowski (1866-1940), Stanisław Pigoń (1885-1968), and Stanisław Windakiewicz (1863-1943), sociologist and ethnologist Jan Stanisław Bystroń (1892-1964), and historian Władysław Semkowicz (1878-1949). ${ }^{10}$

For a few years, Boruchowicz and Cyrankiewicz managed the activities of the Academic Association of Pacifists (hereinafter AZP - Akademicki Zwiąek Pacyfistów) and the Academic Association of Drama Lovers. Members of the first association included Janina Bogucka; Krystyna Markówna; Feliks Bocheński; writer, theater critic, and translator Wojciech Natanson (1904-1996); socialist and sociologist Feliks Gross (1906-2006); art historian Karol Estreicher (1906-1984); Józef Krzyżanowski; Jerzy Górski; writer and critic Andrzej Banach (1910-1990); linguist Stanisław Urbańczyk (1909-2001); poet and prose writer Stanisław Dobrowolski (1907-1985), and many others. The usual, crowded AZP gatherings were attended by people holding various political opinions and were characterized by free speech. Thanks to financial assistance from minister Franciszek Sokal (1881-1932), a delegate of the Republic of Poland to the League of Nations, this association sent interns to the International Labour Office (BIT) in Geneva. As Boruchowicz himself recalled years later, the AZP protested

heavily against the accession of Hitler to power in Germany, against the anti-Polish rhetoric of the 'classical' German right and Nazism; the day before Hitler rose to power, it hosted German Catholic pacifists who courageously and unambiguously opposed the predatory tendencies of their compatriots. After Hitler's assumption of power and the Reichstag fire, it continued to expose Hitler's military preparations, which got them calling us 'war instigators. "11

\footnotetext{
7 Capable of military service during times of peace and war.

${ }^{8}$ Boruchowicz Maks. Jagiellonian University Archives (hereafter: AUJ), ref. WF II 438, 1930/31 A-K; WF II 445, 1931/32 A-K; WF II 453, 1933/34 A-K; WF II 457, 1934/35 A-K; WF II 461, 1935/36 A-K; WF II 465, 1936/37 A-K; WF II 470, 1937/38; S II 369, 1930/31 A-B; S II 377, 1931/32 A-B; S II 393, $1933 / 34$ A-B; S II 401, 1934/35; S II 417, 1936/37; S II 425, 1937/38 (all volumes without pagination).

9 Ibid; Gawron 2014: 123.

10 Prokop-Janiec 1992: 53.

11 Borwicz 1964b: 148.
} 
The association took part in many different initiatives, such as the defense of Carl von Ossietzki (1889-1938), a German journalist, writer, pacifist, and 1935 Nobel Peace Prize winner who spent the last eight years of his life in prison and concentration camps (where he died) for revealing confidential military information on the armaments of the Reichswehr, despite restrictions enshrined in the Treaty of Versailles. ${ }^{12}$

It is worth adding that gatherings of the Academic Association of Pacifists, just like those of the Academic Association of Drama Lovers, usually took place weekly in the evening in Copernicus Room (Sala Kopernika) in Collegium Novum at 24 Gołębia Street. The meetings of both associations were relaxed and allowed free discussion and presentation of multiple viewpoints. These "dramatic" meetings focused on current and sometimes controversial literary affairs being addressed in the press, as well as major theatre premieres. They were faithfully attended by authors, actors, directors, painters, and theatre and other critics. In addition to these were gatherings organized by Litart, a literary and artistic association (established by a group of leftist activists which operated from 1926-1935, and which was reformed from the Helion association, whose members included Roman Brandstaetter, Leon Kruczkowski, Marian Czuchnowski, and Lech Piwowar), ${ }^{13}$ to which Boruchowicz and the majority of the right-wing Association of Polonists belonged. As Boruchowicz later recalled, some of these meetings were disturbed by "national youth" from the latter association, who blocked the entrance to a lecture by Professor Szymanowski and threw eggs at Leon Kruczkowski during a Litart evening devoted to Henryk Sienkiewicz. Furthermore, Cyrankiewicz expressed his opposition to a Nazi invited by the right to one of the lectures by handing "him a bouquet of red roses and asking him to place them on the graves of murdered socialists." 14 Boruchowicz himself also gave a few lectures "on literature and ethics" on behalf of the Association for the Promotion of Maternity. ${ }^{15}$

Boruchowicz finished his university education in 1937 without obtaining a master's degree, despite the fact that in 1933 he had passed two master's examinations on his first attempt, one in the history of Polish literature (on 14 December, with a mark of "good") and the other in the history of German literature (on 13 December, with a mark of "very good"). ${ }^{16}$ The reason for this is unknown. Was it because he was too involved in extracurricular work focused on politics? (After all, he was probably a member of the Polish Socialist Party from 1936, and a member of the "Achdut" Academic Association of Zionists and Socialists from 1937. ${ }^{17}$ ) Or was his extracurricular work focused more on literature and journalism?

12 Ibid.

13 Lubas 1984: 585.

14 Borwicz 1964b: 149-150, 152.

15 Borwicz 1964a: 156.

16 Boruchowicz Maks. AUJ, ref. KM 84 A-J, no pagination.

17 Czachowska 1994: 229; Document No. 301 - 23 June 1937. List of candidates for delegates from Western Lesser Poland and Silesia for the 20th Zionist Congress, in: Brzoza 2015: 478; Document No. 305 23 October 1937. An appeal of the "Achdut" Academic Association of Zionists and Socialists for support of its activities, in: Ibid: 482. 


\section{Literary activity}

Boruchowicz made his literary debut rather early with an academic article entitled Cyganeria warszawska (Varsovian Bohemia), which was published in Kurier LiterackoNaukowy (Scientific and Literary Messenger), a Sunday supplement to issue no. 7 of $\mathrm{Il}$ ustrowany Kuryer Codzienny (Illustrated Daily Messenger) from 16 February 1931. In it he recalls the history and work of a group of young artists from Warsaw active from 1839 to 1843 , from whom he most likely took inspiration when forming the abovementioned literary and political academic associations. It is worth quoting the end of this article, which may have also been a manifesto of the author himself. The members of Bohemia, he wrote, "wanted to express their own feelings and judgements. They wanted to break away from a strict and sacred machine in which individuals are just a collection of conveyor belts and modes. Together, their lives would be [...] a contribution to the history of artistic groups emerging from the pincers of mindless norms." ${ }^{18}$

In addition, Boruchowicz worked for many other journals, including Nowy Dziennik (New Daily, in which he edited the "Among Poets" section and others from 1933 to 1937), Gazeta Artystów (The Artists' Gazette, an artistic and social weekly, 1934), Tygodnik Artystów (Artists' Weekly, 1935), Czas (Time, 1935-1936), Chwila (Moment, where he published theatre reviews from 1937 to 1938, Lviv), Sygnaty (Signals, 1937, Lviv), Życie Świadome (Conscious Life, a quarterly devoted to sexual and moral reform issues, 1936-1937), Nasza Opinia (Our Opinion, 1937-1938), and Nasz Wyraz (Our Expression, an artistic and literary monthly, 1938-1939). In 1936 he won first prize in Wiadomości Literackie (Literary News) for his column. ${ }^{19}$

Furthermore, he co-edited Albo-Albo (Either-Or), a Kraków social and literary biweekly, with several authors, including Adam Ciołkosz (1901-1978), a leader of the Polish Socialist Party and a member of parliament, and Leon Kruczkowski (1900-1962), a writer and publicist. It was advertised in the press as a magazine that "brings together the best progressive and democratic Polish writers. ${ }^{20}$ From 1937 to 1938, a total of 12 issues of the magazine were published, each 6-8 pages long. Its editorial office was located on the first floor of tenement building no. 4 at Plac Zgody (Concord Square, currently Plac Bohaterów Getta, or Ghetto Heroes' Square) in Kraków; Eugeniusz Mroczek was its publisher and executive editor. During the second year of its publication, a second department was established in Warsaw at 12/7 Szczygla Street. ${ }^{21}$

The agenda of the magazine is best reflected in an editorial by Adam Ciołkosz in the first edition, entitled Chcemy być mlotem (We Want to Be a Hammer). The first two paragraphs appear to still be valid:

\footnotetext{
18 Boruchowicz 1931: 9.

19 Borwicz Michat Maksymilian (born 1911) 1963: 236; Borwicz (Boruchowicz) Michat Maksymilian (1911-1987) 1992: 43; Czachowska 1994: 228-229; Boruchowicz M. 1933; Boruchowicz M. 1934b; Boruchowicz 1936a: 18-23; [Boruchowicz M.] 1936b; [Boruchowicz M.] 1936c; Boruchowicz 1937a; Boruchowicz 1937b; Boruchowicz 1938d; Boruchowicz 1939: 4.

${ }^{20}$ [Advertisement] 1937: 20.

${ }^{21}$ Biography of M. Borwicz [1985?]. Polish Library in Paris (hereinafter PLP), ref. Akc 3485, without pagination.
} 
We are going through a time when all the good and bad of humanity is swirling together. Old, pre-war times, in which everything was known, sorted, and marked, are irretrievable. Nearly two-thirds of the population today does not remember them, for time is always winding down a new path. Have the doctrines we consider our signposts changed? Faith has not changed, but external conditions are undergoing a very thorough transformation. It is good to have a compass at sea during a storm, but only if one knows how to use it. We shall use our compass diligently, that we may not lose our way on the rolling waves; that we may, night or day, seek and find our way with confidence.

$\mathrm{O}$, these times of turmoil! In the midst of great events we are witnessing changes so great and fast that one generation today must carry a burden large enough for several. We are not merely spectators. Whether we want it or not, the responsibility for today and tomorrow has fallen on us all. We must choose: either - or. For democracy means responsibility. Responsibility for everyone. We are all writing the pages of history, and no one is a bystander, even if he thinks he is. There is no escape from reality, no way to stand passively and wait. We can only choose a spot in the first, second, or third line of fighters. We can either be a hammer or an anvil. We want to be a hammer. ${ }^{22}$

The editorial is supplemented by a text from Leon Kruczkowski entitled ALTERNATYWA (alternative), also on the first page of the edition:

We who love freedom and human dignity, enjoy work, and value welfare, must clearly and emphatically, persistently and assertively, project onto the screen of today an irresistible ALTERNATIVE that will soar above the earth with wings spread wide.

You must choose:

EITHER a free existence, OR deposition and yoke

EITHER a republic of labor, built by free hands, OR a camp of general misery fenced by barbed wire

EITHER fertility and beauty, OR disgrace and trampling

EITHER clarity of thought, OR deep night draped over battered consciences

EITHER a people's democracy, OR fascism

You choose, citizens!

We need indefatigable drummers who with their tight snares will stimulate minds, hearts, and wills to decision.

Let it not be said one day that you chose this historical ALTERNATIVE too late! ${ }^{23}$

Boruchowicz was often featured in the magazine, writing about engaged literature (by Louis-Ferdinand Céline, Stanisław Brzozowski, and Karol Irzykowski), Nazism, and Hitlerism. ${ }^{24}$ His journalism during this period was also highly politicized. He openly stigmatized nationalism and racism, both in the Polish (where he listed specific names) and foreign editions. On the third page of the first issue of Albo-Albo was Boruchowicz's article, Sztuka "zwyrodniata” i zwyrodnialcy ("Degenerate" art and degenerates), in which he described new cultural initiatives of the German government. He also organized two art exhibitions. The first presented "works of the revived Germanic spirit," and the second "rotten, cursed, and degenerate art." The former was poorly attended, but the latter drew crowds. ${ }^{25}$

\footnotetext{
22 Ciołkosz 1937: 1.

23 Kruczkowski 1937: 1.

24 Boruchowicz 1938e: 2; Boruchowicz 1938g: 1; Boruchowicz 1938a: 3; Boruchowicz 1938c: 5-6.

25 Boruchowicz 1937c: 3.
} 
Furthermore, in an article published in the Artists' Gazette, Boruchowicz directly referred to the activities of Stanisław Piasecki (1900-1941), a well-known nationalist, writer, journalist, former member of the "All-Polish Youth" Academic Association, and founder of Prosto z Mostu (Straight from the Bridge), a literary and artistic weekly. He wrote that Piasecki, after reading Jan Czekanowski's Outline of Polish Anthropology, in which he found the results of studies aiming to determine the percentage to which Jewish students from the University of Lviv were Nordic, was forced to acknowledge that the natural theory of racism was senseless. Piasecki therefore declared a theory of psychological racism based on the idea of a specific type of love and natural drive for independence. He proclaimed: "There may be something in this as mysterious as love... I know that others are more beautiful, wiser, and richer, but I like the one that is ugly, simple, and poor." In other words, "This stranger has reached psychological heights in a given field and will pull me up to those heights with him? We want to reach those heights ourselves. By our own work and effort, because perhaps others of our psychological race will clear paths to the same destination. ${ }^{" 26}$ According to Boruchowicz, everything would have been fine if Piasecki and others like him had not, in an effort to impose their will, brought third persons into this love. He concluded:

If the right cannot afford rational love, love that requires self-criticism, it can be freely substituted by something lesser. As long as it exists in their own family circles. To boast about irrational nonsense in public shows a lack of good taste at the least. And gnashing of teeth and intimidation with clubs already smacks of psychopathy. Because these morbid tendencies are accompanied by a pseudoscientific theory, they constitute a unique psychiatric case: premeditated psychopathy. ${ }^{27}$

As we can see, Boruchowicz, like Norwid before him, attempted to "name the phenomenon" ("odpowiednie dać rzeczy słowo").

It should be added, however, that Boruchowicz, the co-editor of Albo-Albo, was not just a journalist. In 1938, after some perturbations in its publication, his first and only novel was printed: Miłość i rasa $^{28}$ (Love and Race), a vivisection of Hitlerism. ${ }^{29}$ It is set in Germany from 1928 to 1935 and describes the environment of German Marxists and national socialists, whose conflict escalates after Hitler's rise to power. It portrays the development of Nazi terror and the use of ruthless methods by the new regime, which breaks weak and passive individuals and forces those who refuse to cooperate into deadly combat. The Nazis and the Jews gradually emerge as the main characters in the struggle. Boruchowicz's debut novel was warmly received by literary critics. ${ }^{30}$

At this time, Boruchowicz also gave historical and literary talks on Polish Radio in Kraków (established in 1927) and compiled a monograph on Stanisław Brzozowski (1878-1911), a philosopher, writer, journalist, proponent of historical materialism, and theater and literary critic from the Young Poland era. On the eve of the outbreak of World War II, Boruchowicz was staying in Geneva, whence he was conscripted back to

\footnotetext{
26 Boruchowicz 1934a: 3.

27 Ibid.: 4.

28 A fragment of it was published earlier in Albo-Albo. Boruchowicz 1938f: 2.

29 Boruchowicz 1938b.

30 Żer[omska] 1938: 6.
} 
Poland. ${ }^{31}$ As soon as the war began, he became a wanderer. (This may be the topic of a future discussion.) After the war, under his new name, Michał Borwicz, he returned to Kraków and became director of the Regional Jewish Historical Commission and vice director of the Central Jewish Historical Commission, as well as a member of the editorial boards of the publishing houses of these institutions. In March of 1947, under threat of arrest, he fled to Stockholm, and from there emigrated to France in July of the same year.

\section{Summary}

In describing Boruchowicz's pre-war life, we should focus above all on his humanistic education, together with his literary talent and political sophistication. Although he came from an assimilated family, he did not renounce his Jewish origins. On the contrary, during his university studies, he openly admitted that he was Jewish, that his native language was Hebrew (only in a survey from his first year did he mark his native language as Polish), and that he practiced Judaism. However, it seems that with regards to the Hebrew language, this was only a demonstration in defense of the independence of Jewish culture against the growing anti-Semitism also at Polish universities, because Boruchowicz did not know the language at that time. Also, while at university he published frequently and was actively involved in literary, cultural, educational, and political activities. Courage in the formulation of judgements, polemical giftedness, and social commitment would also characterize him later in life.

Finally, I would like to point out that this article has only signaled a number of threads in Michał Borwicz's rich biography in the so-called Kraków period, which will be developed in the future in terms of both his cultural and political activities. It is in preparation for my next article, entitled "Saved by socialism? PPS threads in the life of Michat

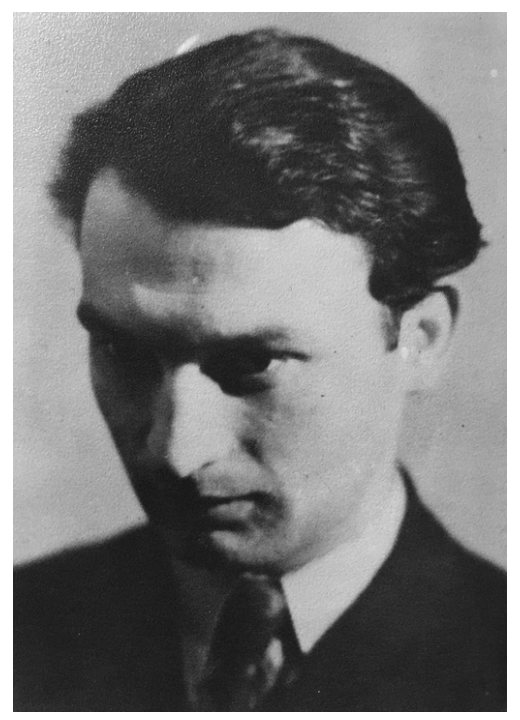

${ }^{31}$ Czachowska 1994: 228-229.
Borwicz (1911-1987)," based on new sources and studies of the topic, which in the original version was presented at the conference "Biographies and politics. The involvement of Jewish origin in leftist movements in 19th and 20th century Poland" at the POLIN Museum of the History of Polish Jews in Warsaw (1-2.12.2019).

Michał Borwicz, 1937

Source: Author's personal archive 


\section{BIBLIOGRAPHY}

\section{Archival sources}

National Archives in Kraków ref. GMJ 24, sheet 245, 249v; GMJ 84, sheets 17-17v.

Jagiellonian University Archives, Boruchowicz Maks, ref. KM 84 A-J; WF II 438, 1930/31 A-K; WF II 445, 1931/32 A-K; WF II 453, 1933/34 A-K; WF II 457, 1934/35 A-K; WF II 461, 1935/36 A-K; WF II 465, 1936/37 A-K; WF II 470, 1937/38; S II 369, 1930/31 A-B; S II 377, 1931/32 A-B; S II 393, 1933/34 A-B; S II 401, 1934/35; S II 417, 1936/37; S II 425, 1937/38.

Polish Library in Paris ref. Akc 3485.

\section{Published sources}

[Advertisement] (1937), Życie Świadome [Conscious Life] 2 (2): 20.

Boruchowicz, M. (1931), Cyganerja warszawska (W dziewięćdziesiątą rocznicę) [Varsovian Bohemia (The 90th anniversary of])], Kurier Literacko-Naukowy [Scientific and Literary Messenger] 8 (7): 9.

Boruchowicz, M. (1933), O polsko-żydowską poezję. Na marginesie pewnej dyskusji [On Polish-Jewish poetry. On the margins of certain discussions], Nowy Dziennik [New Daily] 263.

Boruchowicz, M. (1934a), Irracjonalizm, miłość i chorobliwe pretensje [Irrationalism, Love, and Pathological Grievances], Gazeta Artystów [Artists' Gazette] 1 (10): 3.

Boruchowicz, M. (1934b), Pożegnanie młodości [Farewell to youth], Nowy Dziennik [New Daily] 125.

Boruchowicz, M. (1936a), Czy nie czas skończyć z frazesem o „życiu ułatwionym”? [Can We Stop Talking About an "Easier Life"?], Życie Świadome [Conscious Life] 1 (3): 18-23.

[Boruchowicz, M.] m. b. (1936b), Wśród książek. „Na cienkiej strunie”. Poezje Andy Eker [Among books. "On a thin string." Poetry of Andy Eker], Nowy Dziennik [New Daily] 8.

[Boruchowicz, M.] m. b. (1936c), Wśród poetów'(Among the poets), Nowy Dziennik [New Daily] 107.

Boruchowicz, M. (1937a), Brzozowski and Malraux, Sygnaty [Signals], [offprint 32].

Boruchowicz, M. (1937b), Fizjologia rozpaczy i nihilizmu (L.F. Céline i nasze czasy) [The Physiology of Despair and Nihilism (L.F. Céline and Our Times)], Życie Świadome [Conscious Life] 2 (6), [offprint: 12].

Boruchowicz, M. (1937c), Sztuka „Zwyrodniała” i zwyrodnialcy [“Degenerate” Art and Degenerates], Albo-Albo [Either-Or] 1 (1): 3.

Boruchowicz, M. (1938a), Autora „Lżejszego kalibru” - dzieje grzechu [The Author of “A Lighter Caliber": A History of Sin], Albo-Albo [Either-Or] 2 (9): 3.

Boruchowicz, M. (1938b), Miłość i rasa. Powieść [Love and Race: A Novel], Kraków.

Boruchowicz, M. (1938c), Rewelacje? - być może [Revelations? Maybe], Albo-Albo [Either-Or] 2 (10): 5-6.

Boruchowicz, M. (1938d), Stanisław Brzozowski. Widma moich wspótczesnych [Stanisław Brzozowski. The Phantoms of My Contemporaries], Nasz Wyraz [Our Expression], March.

Boruchowicz, M. (1938e), Szlakiem „zdobywcy”. (Piewca duszy człowieka brunatnego [Louis-Ferdinand Céline]) [Path of a Conqueror: The Singer of a Brown Man's Soul (Louis-Ferdinand Céline)], Albo-Albo [Either-Or] 2 (4): 2.

Boruchowicz, M. (1938f), W cieniu gotyckich wież [In the Shadows of Gothic Towers], Albo-Albo [Either-Or] 2 (6): 2.

Boruchowicz, M. (1938g), W przededniu jubileuszu i w rocznicę „Sprawy” Stanisława Brzozowskiego [On the Eve of the Jubilee and on the Anniversary of the "Stanisław Brzozowski Affair"], AlboAlbo [Either-Or] 2 (7): 1.

Boruchowicz, M. (1939), Petroniusz „na nowo napisany”. (W związku z nowym wydaniem „Samego wśród ludzi” [Stanisława Brzozowskiego]) [Petronius Rewritten: In Connection with the New Edition of "Alone Among People" (by Stanisław Brzozowski)], Nasz Wyraz [Our Expression] 2: 4.

Borwicz, M.M. (1964a), Listy do Redakcji. Paryż, listopad 1964 [Letters to the Editor. Paris, November 1964], Kultura [Culture] 12 (206): 156. 
Borwicz, M.M. (1964b), „...Zabawy, spory w one lata” [“...Entertainment and Disputes of These Years"], Kultura [Culture] 9 (203): 148.

Brzoza, C. (ed.) (2015), Żydzi krakowscy w okresie międzywojennym. Wybór dokumentów [Kraków Jews in the Interwar Period: A Selection of Documents], Kraków: 478, 482.

Ciołkosz, A. (1937), Chcemy być młotem [We Want to Be a Hammer], Albo-Albo [Either-Or] 1 (1): 1.

Kruczkowski, L. (1937), ALTERNATYWA [ALTERNATIVE], Albo-Albo [Either-Or] 1 (1): 1.

Żer[omska], M. (1938), Miłość i rasa [Love and Race], Albo-Albo [Either-Or] 2 (10): 6.

\section{Literature}

Borwicz (Boruchowicz) Michat Maksymilian (1911-1987) (1992), in: Klimaszewski, B., Nowakowska, E.R., Wyskiel, W., Maty stownik pisarzy polskich na obczyźnie 1939-1980 [A Small Dictionary of Polish Writers in Exile 1939-1980], Klimaszewski, B. (ed.), Warszawa: 43.

Borwicz Michat Maksymilian (ur. 1911) [Borwicz Michał Maksymilian (b. 1911)] (1963), in: Korzeniewska, E. (ed.), Słownik wspótczesnych pisarzy polskich. Tom pierwszy a-i [Dictionary of Contemporary Polish Writers. Volume I a-i], Warszawa: 236.

Czachowska, J. (1994), Borwicz Michat Maksymilian 1911-1987, in: Czachowska, J., Szałagan, A. (eds.), Współcześni polscy pisarze i badacze literatury. Słownik biobibliograficzny. Tom pierwszy $A-B$ [Modern Polish Writers and Researchers of Literature: A Biobibliographical Dictionary, Volume I A-B], Warszawa: 229.

Gawron, E. (2014), Michat Maksymilian Borwicz, in: Borwicz, M.M., Uniwersytet zbirów. Rzecz o obozie janowskim we Lwowie 1941-1944 [University of Thugs: On the Janowska Concentration Camp in Lviv 1941-1944], Kraków: 123.

Lubas, R. (1984), Litart, in: Krzyżanowski, J., Hernas, C. (eds.), Literatura polska. Przewodnik encyklopedyczny. T. 1: A-M [Polish literature. Encyclopedic guide. Vol. 1: A-M], Warszawa: 585.

Prokop-Janiec, E. (1992), Międzywojenna literatura polsko-żydowska jako zjawisko kulturowe i artystyczne [Polish-Jewish interwar literature as a cultural and artistic phenomenon], Kraków: 53.

Quercioli Mincer, L. (2014), Dwa wiersze z Szeolu. Zagłada Żydów w okupacyjnych tekstach Czesława Miłosza [Two Poems from Sheol: Extermination of the Jews in Czesław Miłosz's Occupation Texts], in: Bilczewski, T., Marinelli, L., Woźniak, M. (eds.), Rodzinny świat Czesława Miłosza [The Familial World of Czesław Miłosz], Kraków 2014: 187.

Scharf, R. (1988), Michał Borwicz, Polin, vol. 3: 458-462. 